\title{
Effect of Charge Temperature on Performance of 4s Single Cylinder Twin Spark SI Engine
}

\author{
Nandan Kumar, Rashmi Dwivedi, Prem Kumar Chaurasiya, Sanjay Chhalotre, Sanjay Kumar \\ Singh
}

\begin{abstract}
This study involves the analysis of the performance improvement of the air-cooled SI engine by controlling the charge temperature. The insulated intake manifold has been used to maintaining the charge temperature at the atmospheric temperature level. The effect of variation in intake air temperature coming from atmospheric temperature on the engine performance in terms of brake mean effective pressure, engine power, engine torque are investigated. The result indicated that the mass flow rate of air is increased after using cold and insulated air intake system with average air density of 1.174 $\mathrm{kg} / \mathrm{m3}$. This improved air intake mass flow rate increased the brake torque and a reduction in exhaust gas emission. The result shows when the air-fuel mixture allowed for combustion at atmospheric intake air temperature $\left(30^{\circ} \mathrm{C}\right)$, the engine produces $1.2003 \mathrm{~kW}$ power and $5.7314 \mathrm{~N}-\mathrm{m}$ torque at $2000 \mathrm{rpm}$. The engine performance calculated at an engine speed of 1000, 1500 and 2000 rpm.
\end{abstract}

Keywords: Air density, Intake charge temperature; Spark ignition engine; Heat loss; Emission

\section{INTRODUCTION}

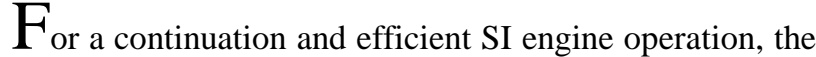
heat transfers after the combustion are extremely important. During combustion, about $25 \%$ to $30 \%$ of the energy produces by the burning of the air-fuel mixture is passed away from the engine cylinder through the exhaust gas residuals. During the combustion, the combustion chamber temperature increases up to $2000^{\circ}$ Celsius. The material like aluminum alloys is used for manufacturing the light-weighted new generation engine components, which are damaged because of seizing effect at this temperature if the heat dissipation rate is not efficient in an air-cooled engine at different engine speed. To cool down the engine by removing the heat from the running engine is the highly critical work. Commonly two types of method are used to cool down the engine or keep the engine temperature at moderate level.

Revised Manuscript Received on April 18, 2020.

* Correspondence Author

Nandan Kumar*, M.Tech, Thermal Engineering, Sagar Institute of Science and Technology, Gandhi Nagar Bhopal.

Rashmi Dwivedi, Associate Professor, Sagar Institute of Science and Technology, Gandhi Nagar Bhopal.

Prem Kumar Chaurasiya, Associate Professor, Sagar Institute of Science and Technology, Gandhi Nagar Bhopal

Sanjay Chhalotre, Professor, Sagar Institute of Science and Technology, Gandhi Nagar Bhopal.

Sanjay Kumar Singh, Professor, Sagar Institute of Science and Technology, Gandhi Nagar Bhopal

(C) The Authors. Published by Blue Eyes Intelligence Engineering and Sciences Publication (BEIESP). This is an open access article under the CC BY-NC-ND license (http://creativecommons.org/licenses/by-nc-nd/4.0/)
The methods are air cooled by creating fins on outer surface of the engine head and block and by water cooled, where water circulate in predefine paths called water jackets surrounding the cylinder in side of the engine. The lubrication oil also helps too carried away engine heat during circulation in engine component. With continue engine operation it's difficult to maintain the lubrication property of the engine oil and prevent the losses of oil by means of evaporation. Improper cooling of engine damages the engine components like piston, piston rings, valves, gaskets etc. along with reducing the viscosity property of engine lubricant and increases the air fuel mixture evaporation and increases NOx [1-4]. For efficient and long lasting SI engine performance it should be mandatory to avoid engine knock and pre ignition of charge by controlling the temperature of combustion chamber and exhaust valve [5]. The air -fuel charge prepares by carburetor in the spark ignition engine [6]. The proper combustion of SI engine is controlled by the number of moles of oxygen present in the charge [7-8]. The rate of combustion has been increased by reducing the charge temperature [9]. Getting uniform cooling from all sides of air cooled engine is highly difficult. The cooling of front side of an engine towards the direction of vehicle motion is easy and efficient. The volumetric efficiency of SI engine is affected, if low density intake air allows for combustion [10]. The air-cooled engine transfers the heat by conduction and radiation caused the nearby components like intake manifold, carburetors, and air filter box also get heated. This preheated intake air and air-fuel charge increase the pre cyclic temperature of the IC engine [11]. The moderately heated intake air system, slightly more than the atmospheric temperature increases the fuel evaporation rate which is helpful to mix oxygen moles present in the air with each fuel particles and give homogeneous mixture [12]. But the too much-heated air intake manifold increases the evaporation rate of fuel and reduces the density of intake air. The less-dense air means a lack of oxygen moles which directly affected the performance of the engine [15]. When the intake air passes through the heated intake manifold with the fuel particles, due to the excess temperature the air losses its density result it slows the flame propagation rate in the combustion chamber. the slow flame propagation rate increases the engine thermal losses [16]. During the compression stroke, the temperature and pressure of the air-fuel mixture have rapid increases, which are helpful to minimize the ignition lag period cause a quick start of the cold engine.

Published By:

Blue Eyes Intelligence Engineering \& Sciences Publication 
But if the initial temperature of the intake charge is higher than the atmospheric temperature increases the pre cyclic temperature of the engine from the beginning. For long engine operation, it has increased the rate of knocking tendency because of surface and pre-ignition. Excessive knocking reduces the engine's life [17]. In this practical investigation we measure the effect of variation in intake air temperature coming from atmospheric temperature on the engine performance in terms of brake mean effective pressure, engine power, engine torque. When the charge temperature increases the evaporation of the fuel also increases and gives better distribution of the heavier fuel fractions which reduces the tendency to detonate. Also there is a reduction of the density of the charge with an increase in mixture temperature, which further decreases the combustion pressure reducing the tendency to detonate.The exact proportion of the energy supplied to the engine (as fuel) which is converted into useful work is critically influenced by many physical characteristics of the engine such as engine design, type of the fuel used, Cooling system, etc. In general, about 30 per cent of the energy supplied is converted into useful work; about 30 per cent is lost as exhaust heat and some energy is lost in friction, compression and direct rejection from engine. The rest of the energy, about 30 per cent, has to be removed by the cooling system if it is not to increase the engine temperature while running.

Piston, cylinder liner and head are subjected to very high temperatures because they are in direct contact with the hot combustion gases.

The lubricating oil used for lubrication also helps to cool down the engine component. Normally the temperature of lubricating oil goes up to $160^{\circ} \mathrm{C}$ to $200^{\circ}$ Celcicus in an air-cooled engine. Above these temperatures, the viscosity level of lubricating oil deteriorates very fast as the temperature increase causes damage to the engine.

The strength of the materials used for various engine parts usually decreases with an increase in temperature, and thus establishes an upper limit for the temperatures at various points of the engine. For example, for water-cooled engines, the temperature of the cylinder head should not exceed about $270^{\circ} \mathrm{C}$ while for air-cooled engines, which use light alloys, this limit is as low as $200^{\circ} \mathrm{C}$.

\section{METHODOLOGY}

To protect the intake manifold by the engine thermal losses, through conduction and convection, the intake manifold insulated by Titanium exhaust wrap is made from pulverized lava rock and stranded into a fibre material. It has the ability to handle higher heat for improved performance and durability and with a carbon fibre look. The experiment performs on BAJAJ 125 cc dual spark-ignition single-cylinder air-cooled engine. For measuring the variation in the temperature, the $\mathrm{k}$ - type thermocouple temperature sensors are used, this temperature sensor is installed in the various location of the air-cooled engine like air filter box, inside of the intake manifold, outside the intake manifold (after the insulation) and close to the engine block. The effect of charge temperature on engine performance calculating by using electric dynamometer at different engine speed.

\section{EXPERIMENTAL SETUP}

The experimental test setup engine intake manifold is modified into the insulated intake manifold. The test engine used was a four stroke, single cylinder air cooled petrol engine developing power 11PS at 7500rpm and maximum net torque at $11 \mathrm{Nm}$ at $5500 \mathrm{rpm}$. By the help of this experimental setup we take reading at different engine speed and load condition.
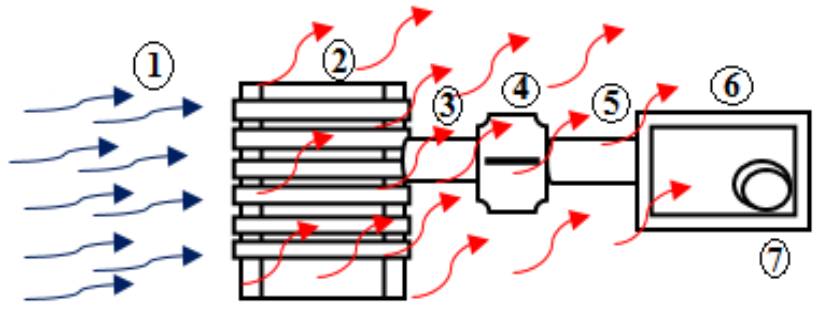

Fig.1. Flow of heat in air cooled engine [4]. 1. Air from ambient, 2 . Air cooled 4 s engine with fins, 3 . Intake manifold 4. Carburetor 5. Air intake hose 6. Air filter assembly 7 . Air inlet

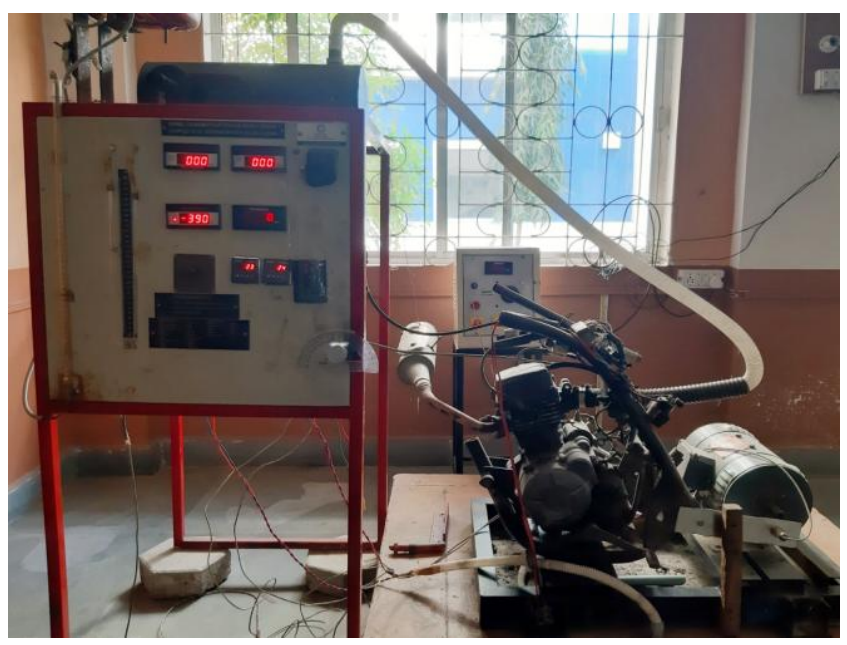

Fig. 2. Experimental setup of 125cc Bajaj DTSI engine

Engine specification

\begin{tabular}{|l|l|}
\hline Engine & 4 stroke , Natural air cooled \\
\hline Bore X Stroke & 52mm X 58.6mm \\
\hline Displacement & 124.45 cc \\
\hline Idling Speed & $1300-1500 \mathrm{rpm}$ \\
\hline Max. Net Power & 11 PS @ 7500 rpm \\
\hline Max. Net Torque & 11 Nm @ 5500 rpm \\
\hline Ignition System & DC, Digital CDI \\
\hline Starting Aid & Kick/Self \\
\hline Spark Plug Gap & 0.7 to $0.8 \mathrm{~mm}$ \\
\hline
\end{tabular}




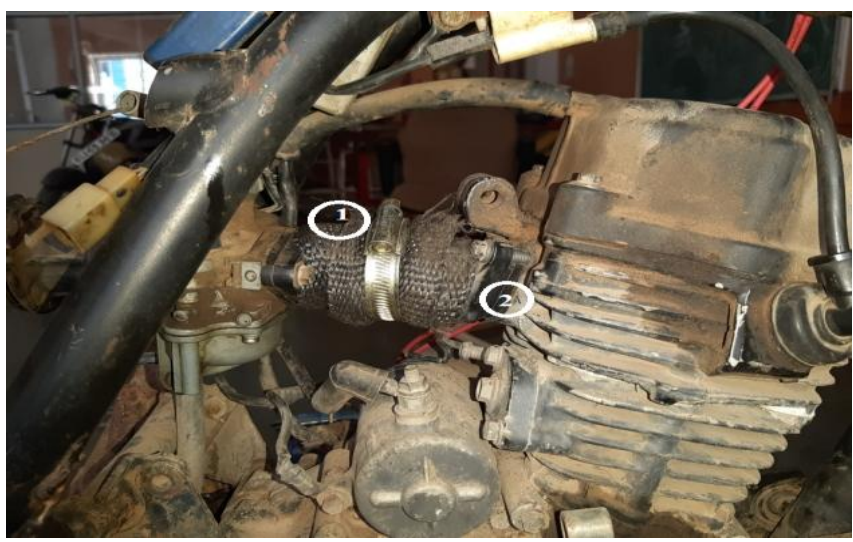

Fig 3. Insulation on the intake manifold, 1. Titanium exhaust

insulation. 2. Polymer rubber connector.

Figure 3 shows the ready experimental setup for reading. The insulated intake manifold connected to the engine block by a polymer rubber connector, to maintain the charge temperature at atmospheric temperature. The insulation and polymer rubber connector have blocked the engine heat transfer rate through the convection and conduction.

The heat transfer rate from air cooled engine is depending upon the length of the fin and the spacing between them. Larger inter-spacing between the fins offers a larger cooling area but the heating of the air is less, so more cooling areas is required smaller interspacing between the fins results in smaller flow areas for cooling air and hence the air is heated more and input to the cooling air.

\section{RESULT AND DISCUSSION}

For this research the test was conducted on Bajaj dtsi dual twin spark engine for engine power, brake mean effective pressure, torque, mass of fuel, specific fuel consumption, indicated mean effective pressure, indicated efficiency, mechanical efficiency, mass flow rate of intake air, volumetric efficiency, exhaust gas temperature.

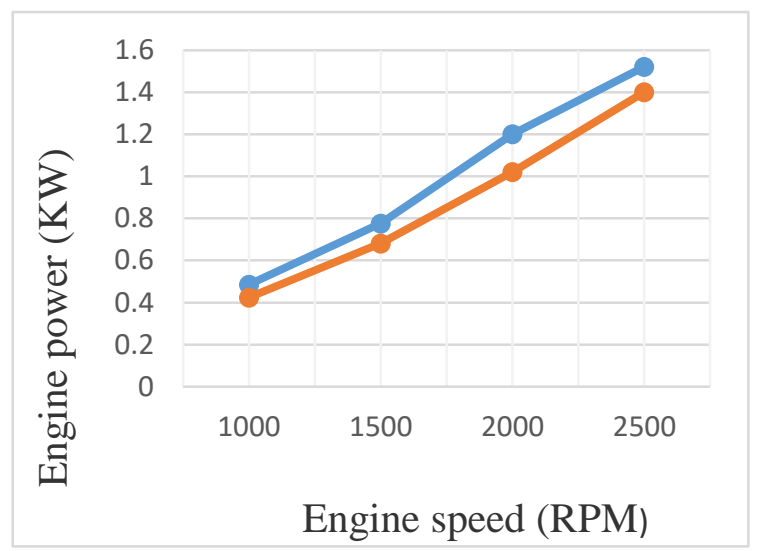

Fig. 4. Engine speed vs engine power (kW)

Fig 4 shows the comparative analysis of engine speed to the engine power, after analyzing the data it shows at $30^{\circ}$ Celsius inlet temperature with insulated air intake manifold, the power output at different engine speed gradually increased but with regular intake system the charge temperature goes up to $85^{\circ}$ Celsius because of heated intake manifold which further reduce the density of charge air cause reduction in mass flow rate and dropped the engine output power.

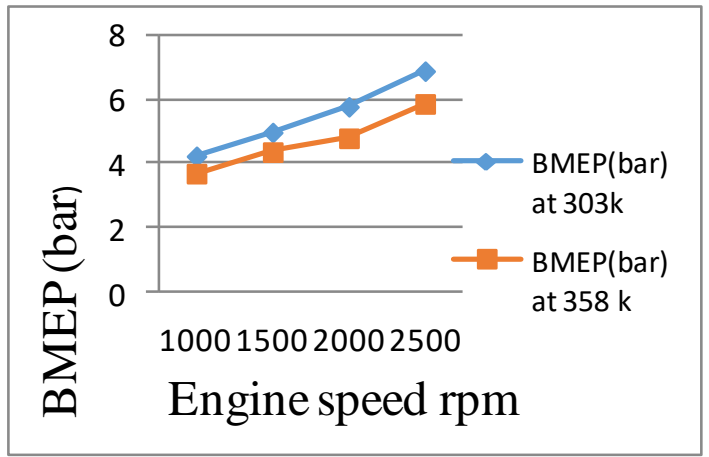

Fig. 5. Engine speed vs BMEP

Fig 5 shows the comparative analysis of engine speed to the bmep. The mean effective pressure inside of the engine cylinder is continuously vary and it is a good parameter to compare engine power output at different variable parameters. For the naturally aspirated spark ignition engines, the bmep vary from 850 to $1050 \mathrm{kPa}$ at different engine speed and the maximum torque is obtained at 3000 rpm. After analyzing the experimental data, it shows at $30^{\circ}$ Celsius charge temperature with insulated air intake manifold the bmep at $2000 \mathrm{rpm}$ is $578.05 \mathrm{kPa}$ were at $85^{\circ}$ Celsius charge temperature the bmep has drop up to $480.73 \mathrm{kPa}$.

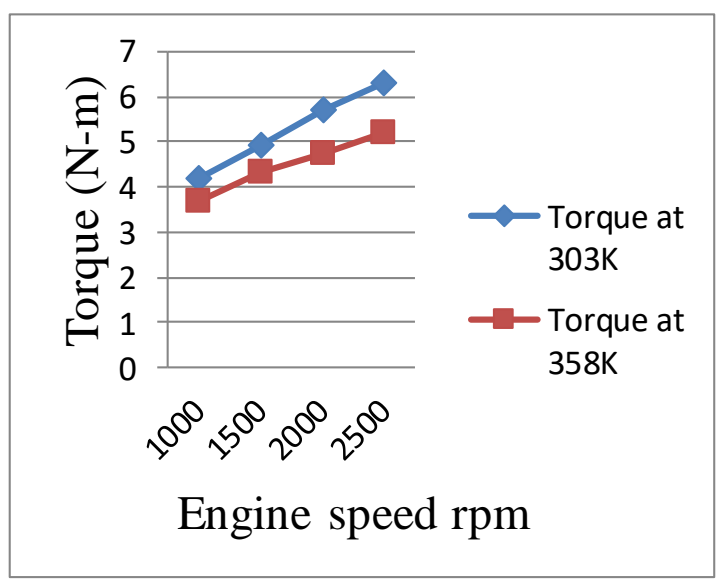

Fig. 6. Engine speed vs Torque

Fig 6 shows the comparative analysis of engine speed to the engine torque, after analyzing the data it shows at $30^{\circ}$ Celsius charge temperature the torque available at $2000 \mathrm{rpm}$ is $5.7314 \mathrm{~N}-\mathrm{m}$ and when the charge temperature reaches up to $85^{\circ}$ Celsius the torque produce by the engine, dropped 4.7665 $\mathrm{N}-\mathrm{m}$ of at the same engine rpm. [18-19].

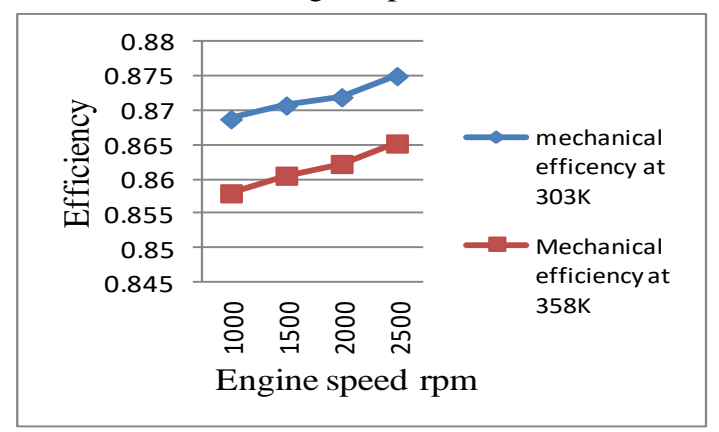

Fig. 7. Engine speed vs Mechanical efficiency

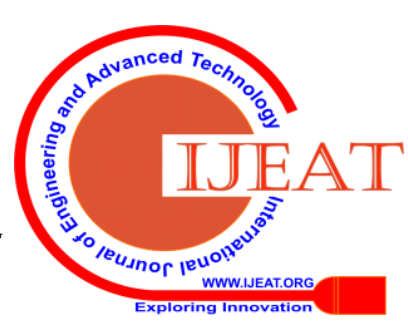


Fig 7 shows the comparison analysis in between mechanical efficiency and engine speed at different charge temperature vary from 30 to $80^{\circ}$ Celsius. At low temperature the mechanical efficiency obtained is $\mathbf{8 7 . 1 9 \%}$ and as the charge temperature increases the mechanical efficiency reduces up to $85.42 \%$. The mechanical efficiency calculated at 2000 engine speed [22-23].

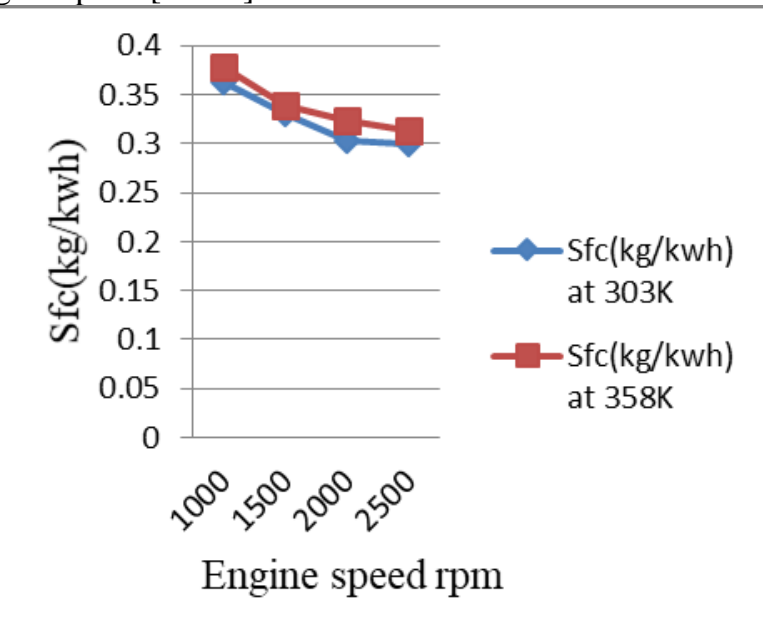

Fig.8. Engine speed vs SFC (kg/kwh)

Fig 8 shows the performance curve in between specific fuel consumption and engine speed. The specific fuel consumption is the fuel flow rate at per unit power output. It shows how economically fuel consumed by the engine to produce output power. The result shows, that the specific fuel consumption at 2000 engine speed is minimum 0.30134 $\mathrm{kg} / \mathrm{kWh}$ when charge allow for combustion at $30^{\circ}$ Celsius temperature. But as the charge temperature increases the specific fuel consumption is also increases up to 0.32320 $\mathrm{kg} / \mathrm{kWh}$ at same engine speed. [20-21]

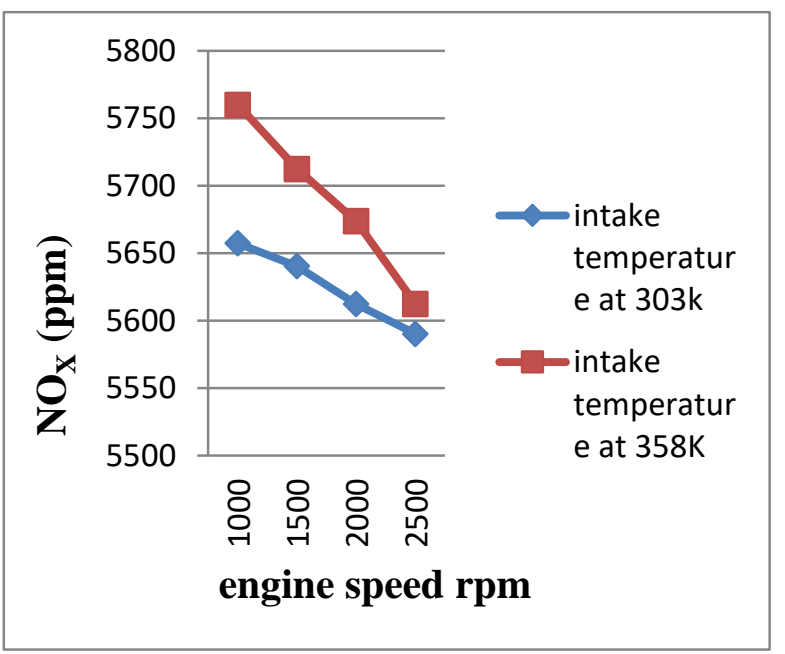

Fig.9. Engine speed vs $\mathrm{NO}_{\mathrm{X}}$

Oxides of nitrogen occurs at high temperature of exhaust gasses. It is a combination of nitric oxide (NO) and nitrogen dioxide $\left(\mathrm{NO}_{2}\right)$. Nitrogen and oxygen react at very high temperature in the combustion chamber and produces NOx. The charge allow for combustion at high temperature increases the pre cyclic temperature of the engine. Cause of this the temperature of combustion chamber increases very rapidly. Fig 9 shows the formation of $\mathrm{NO}_{\mathrm{X}}$ emission with respect to variation in charge temperature. The $\mathrm{NO}_{\mathrm{X}}$ emission produced at low charge temperature is $5527.7 \mathrm{ppm}$ and as the charge temperature increases due to engine thermal losses the level of $\mathrm{NO}_{\mathrm{X}}$ increases up to $5673.6 \mathrm{ppm}$. [22-23].

\section{CONCLUSION}

The temperature of the air-fuel charge affects the performance of the single-cylinder air-cooled SI engine. It is true that the moderate temperature (atmospheric temperature) of the charge helps to prepare a homogeneous charge for, instantaneous and complete combustion. After the start, the engine takes a few minutes to reach a steady-state temperature zone, after that due to variation in driving parameters and load conditions the engine temperature rapidly shootout. The engine temperature maintained by transferring the heat through the mode of heat transfer by conduction and convection when the atmospheric wind velocity passes through the fins available on the surface of the engine head and block. These modes of heat transfer have heated the intake manifold, carburetor, and air filter box which was located behind the engine block. The result of practical experiments shows the surrounding temperature about the block is goes up to $80^{\circ} \mathrm{C}$ to $90^{\circ} \mathrm{C}$ and because of this temperature, the intake charge temperature is also increased causes an increase in the pre cyclic temperature of the engine result intake air loses the density which affects the combustion and volumetric efficiency of the engine. In the presence of low-density air, the air-fuel charge is too lean and evaporates very fast result a drop in power output and torque and increases the NOx emission level.

\section{REFRENCES}

1. G. R. Pucher, D. P. Gradiner, M. F. Bardon, V. Battista, Alternative Combustion Systems for Piston Engines Involving Homogeneous Charge Compression Ignition Concepts - A Review of Studies Using Methanol, Gasoline and Diesel, Fuel, SAE (962062), 1996.

2. M. Christenson, B. Johanson, P. Einewell, Homogeneous Charge Compression Ignition (HCCI) Using Isooctane, Ethanol and Natural Gas - A Comparison with Spark Ignition Operation, SAE (972874), 1997.

3. J. D. Dale, A. K. Oppenheim, Enhanced Ignition for I.C. Engines with Premixed Gases, SAE (810146), 1981.

4. P. Najt, D. E. Foster, Compression Ignited Homogeneous Charge Combustion, SAE (830264), 1983.

5. M. Christenson, N. Johnsson, Influence of Mixture Quantity on Homogeneous Charge Compression Ignition, SAE (982454), 1998.

6. M. Christenson, A. Hultqvist, B. Johnsson, Demonstrating the Multi Fuel Capability of a Homogeneous Charge Compression Ignition Engine with Variable Compression Ratio, SAE (1999-01-3679), 1999.

7. T. F. Ayala, J. C. Keck, J. B. Heywood, Two stage ignition in HCCI combustion and HCCI control by fuels and additives, Combust. Flame, Vol. 132, 2003, pp. 219-239.

8. S. C. Kong, R. D. Reitz, Use of detailed chemical kinetics to study HCCI engine combustion with consideration of turbulent mixing effects, J. Eng. Gas Turb. Power, Vol. 124, 2002, pp.702-707.

9. M. Yao, Z. Zheng, H. Liu, Progress and recent trends in homogeneous charge compression ignition (HCCI) engines, Prog. Energy Combust. Sci. Vol. 35, 2009, pp. 398-437.

10. Z. Peng, H. Zhao, N. Ladammator, Effect of Air-Fuel Ratios and EGR Rates on HCCI Combustion of n-Heptane, A Diesel Fuel, SAE (2003-01-0717), 2003.

11. S. S. Nathan, J. M. Mallikarjuna, A. Ramesh, Effect of charge temperature and exhaust gas re-circulation on combustion and emission characteristics of an acetylene fuelled HCCI engine, Fuel, Vol. 89, 2010, pp. 515-521.

\section{Published By:}

Blue Eyes Intelligence Engineering \& Sciences Publication

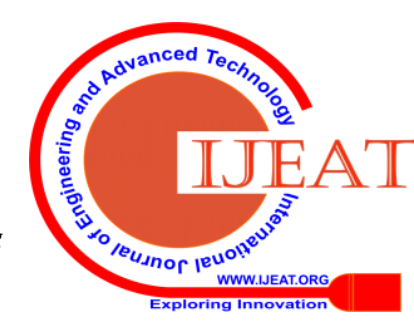


12. X. Lu, Y. Hou, L. Zu, Z. Huang, Experimental study on the auto ignition and combustion characteristics in the homogeneous charge compression ignition (HCCI) combustion operation with ethanol/n-heptane blend fuel by port injection, Fuel, Vol. 85, 2006, pp. 2622-2631.

13. M. Yao, Z. Chen, Z. Zheng, B. Zhang, Y. Xing, Study on the controlling strategies of homogeneous charge compression ignition combustion with fuel of dimethyl ether and methanol, Fuel, Vol. 85, 2006. Pp. 2046-2056.

14. D. Ganesh, G. Nagarajan, Homogeneous charge compression ignition (HCCI) combustion of diesel with external mixture formation, Energy, Vol. 35, 2010, pp. 148-157.

15. M. Fathi, R. K. B. Saray, M. D. Checkel, The influence of exhaust gas recirculation (EGR) on combustion and emissions of n-heptane/natural gas fuelled homogeneous charge compression ignition (HCCI) engines, Appl. Energy, Vol. 88, 2011, pp. 4719-4724.

16. D. S. Kim, C. S. Lee, Improved emission characteristics of HCCI engine by various premixed fuels and cooled EGR, Fuel, Vol. 85, 2006, pp. 695-704.

17. K. M. Rakesh, K.A. Avinash, Experimental investigation on the effect of intake air temperature and air-fuel ratio on cycle-to-cycle variation of HCCI combustion and performance parameter, Appl. Energy, Vol. 88, 2011, pp. 1153-1163.

18. U. Rajak, P. Nashine, T. N. Verma, A. Pugal. Numerical study on emission characteristics of a diesel engine fuelled with diesel-spirulina microalgae-ethanol blends at various operating conditions. Fuel, Vol. 262, 2019, pp.116519 (1-20).

19. U. Rajak, P. Nashine, T. N.Verma. Characteristics of microalgae spirulina biodiesel with the impact of n-butanol addition on a CI engine. Energy, Vol. 189, 2019, pp. 116311.

20. U. Rajak, P. Nashine, T. N. Verma. Effect of fuel injection pressure in a diesel engine using microalgae-diesel emulsion. International Journal of Engineering and Advanced Technology Vol. 8(3), 2019, pp. 263-271.

21. U. Rajak, T. N. Verma. Influence of performance, combustion and emission characteristic using microalgae biodiesel in diesel engine. International Research Publication House, (978-93-87388-21-5), 2018.

22. U. Rajak, P. Nashine, T. N. Verma. Effect of fuel injection pressure of microalgae spirulina biodiesel blends on engine characteristics. JCARME 2019; Accepted.

23. U. Rajak, P. Nashine, T. N. Verma, A. Pugal. Performance and emission analysis of a diesel engine using hydrogen enriched n-butanol, diethyl ester and Spirulina microalgae biodiesel. Fuel, 2020, Accepted.

\section{AUTHORS PROFILE}
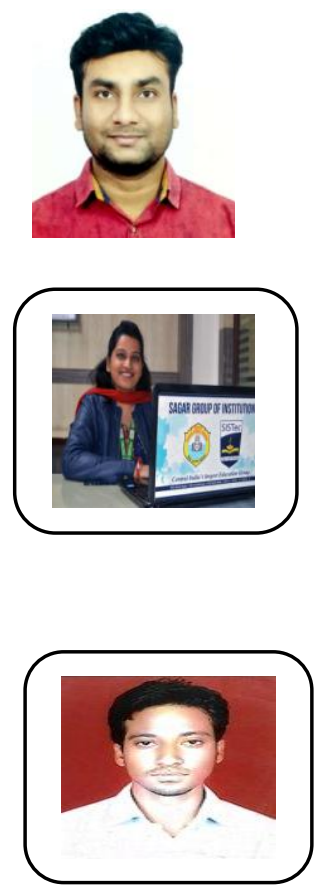

Nandan Kumar Completed his B.Tech in Mechanical Engineering and currently pursuing his M.Tech in Thermal

Engineering from Sagar Institute of Science and Technology, Gandhi Nagar Bhopal. His area of interesr his Heat Transfer, RAC and IC Engines.

Rashmi Dwivedi completed her M.Tech. and Ph.D. from Maulana Azad National Institute of Technology, Bhopal. Presently she is working as an Associate Professor in Sagar Institute of Science and Technology, Gandhi Nagar Bhopal. She has an experience of more than 9 years and has published more than 20 research paper in international journal of repute. She has also guided more than 5 M.Tech. Student.

Prem Kumar Chaurasiya completed his M.Tech. and Ph.D. from Maulana Azad National Institute of Technology, Bhopal. Presently he is working as an Assistant Professor in Sagar Institute of Science and Technology, Gandhi Nagar Bhopal. He has published more than 15 research paper in international journal of repute. Currently, he has been awarded with the International Young Scientist Award.

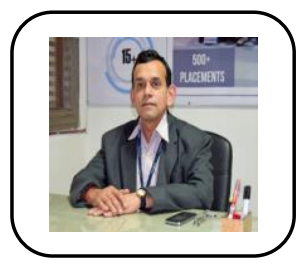

Sanjay Chhalotre is pursuing Ph.D. from Maulana Azad National Institute of Technology, Bhopal. Presently he is working as e Professor in Sagar Institute of Science and Technology, Gandhi Nagar Bhopal. He has an industry experience of more than 20 years and has published various research paper in national and international journal. He has guided more than 10 M.Tech. Student His area of interest include Automobile Engineering, Internal Combustion Engine and Renewable Energy

Sanjay Kumar Singh is pursuing Ph.D. from Maulana Azad National Institute of Technology, Bhopal. Presently he is working as e Professor in Sagar Institute of Science and Technology, Gandhi Nagar Bhopal. He has an experience of more than 15 years and has published more than 20 research paper in international journal. $\mathrm{He}$ has guided more than 25 M.Tech. Student His area of interest include Thermal Energy.

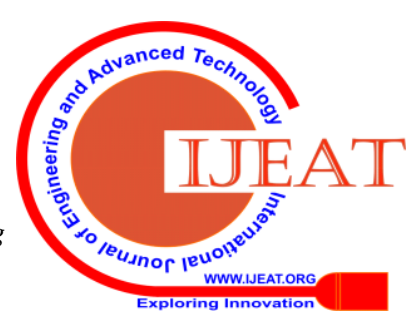

